\title{
DOI https://doi.org/10.30525/978-9934-26-120-6-10
}

\section{ЗОВНІШНЯ ПОЛІТИКА ДЕРЖАВ СВРОПИ ДОБИ РАННЬОГО НОВОГО ЧАСУ В СИСТЕМІ МІЖНАРОДНИХ ВІДНОСИН XVIII СТОЛІТТЯ: ДИПЛОМАТИЧНІ ПРАКТИКИ ТА РЕГІОНАЛЬНО-ІНСТИТУЦІОНАЛЬНІ ДИСКУРСИ}

\author{
Ціватий В. Г. \\ кандидат історичних наук, доцент, \\ Заслужений працівник освіти України, \\ доцент кафедри історії світового украӥнства \\ Київський національний університет імені Тараса Шевченка, \\ член правління
}

Наукове товариство історії дипломатії та міжнародних відносин м. Київ, Україна

Історія міжнародних відносин, зовнішньої політики і дипломатії Криму завжди мала більше запитань, ніж відповідей. А тому постійно цікавила дослідників і вабила своїми таємницями в різних географічних напрямках, зокрема - й європейському. Багато сторінок політичної, дипломатичної та інституціональної історії Криму залишаються мало дослідженими, а частина - очікує ще на своїх допитливих дослідників. На сьогодні ще відсутній системний джерельний комплекс, який би всеохоплююче відтворював би давню, середньовічну, ранньомодерну, модерну історію Криму i надавав достеменно точні, об'єктивні відповіді на поставлені запитання щодо багатовікової історії народів і національних груп півострова, а також - державних інституцій.

Інституціональна історія України, українська культура і національні ідентичності, зокрема - мають історію, що вимірюється багатьма століттями, і багатогранну історико-культурну й ментальну спадщину. Усі регіони України створили власні самобутні культури, що в цілісності й складають українську зовнішньополітичну й політико-дипломатичну палітру. Одним із найсамобутніших і найбагатших регіонів України є Крим. Власне, говорячи про Україну як державу середземноморського культурного простору, насамперед звертаємось до античних колоній Північного Причорномор'я та візантійської теми Херсон. Проте український контекст Криму, як і загалом України, ще наразі не написаний, інституціональна історія державності перебуває в процесі активного дослідження. У часи становлення й розвитку історичної науки, як i загалом гуманітаристики, українські землі загалом, i 
кримські зокрема - перебували під російською окупацією. Та попри те, що Крим як складова частина був чітко вписаний в український контекст найвидатнішим українським істориком Михайлом Грушевським, що чітко сприйнято українською історіографією 3 Великої України, він неоднозначно сприймається на землях Малої України.

Варто зазначити, що не менш цікавим сюжетом щодо Криму, $є$ його інституціональна історія наприкінці раннього Модерного часу, коли Крим став флуктуаційним а́ктором у системі тогочасних політикодипломатичних координат. Історія політичних відносин Кримського ханства, Свропи, Туреччини й Росії завжди була сферою наукових розвідок дослідників. Дослідницький інтерес посилювався неоднозначними відповідями й тривалими інституціональними пошуками щодо трактувань впливів на внутрішні та зовнішні справи Криму трьох впливових політико-дипломатичних сил - Османської імперії, Росії та Свропи. Вони вирішували як власні геополітичні та інституціональні інтереси, так і півострова.

У зв'язку із цим, досліджуючи історію політичних і дипломатичних відносин між Кримським ханством, Османською імперією, Російською імперією та провідними державами Європи, безумовно обов'язково необхідно керуватися виваженими оцінками щодо питань їх впливовості на внутрішню i зовнішню політику ханства, політикодипломатичних взаємовпливів, а також політичних детермінант і флуктуацій. Суспільно-політична та політико-дипломатична ситуація в Криму у 70-х pp. XVIII ст. набувала флуктуаційного характеру (в останній третині XVIII століття). Основними джерелами, які допомагають панорамно та ментально реконструювати політичну ситуацію на Кримському півострові в останній третині раннього Модерного часу $є$ саме матеріали діловодної документації та листування посадовців Кримського ханства та Російської імперії. Цей джерельний масив створився як результат практики діловодства всіх державних інституцій/установ: актові документи, регулюючо-правові документи, ділова документація (донесення, запити, службові листи, скарги, реєстри тощо). Серед діловодної документації між представниками кримського й російського урядів варто виокремити рапорти. У них міститься інформація про отримання наказів, стан їх фактичного виконання. Значний фактологічний матеріал міститься i в такому виді джерел, як - донесення.

У них, поряд 3 інформацією про процес і стан розгляду справ, особливий інтерес являють собою пропозиції, думки, прохання тощо [1]. Основні місця їх зберігання на сьогодні - це фонд «ВУА» Російського державного військово-історичного архіву (РДВІА) [2] i 42 
фонд Внутрішнього управління Російського державного архіву давніх актів (РДАДА) [3]. Під час розгляду конкретних питань, звичайно, що виникало й додаткове листування представників різних державних інституцій. Ці матеріали листування також $є$ діловодною документацією, складають специфічну систему документів і носять офіційний характер. Цей комплекс джерел, у першу чергу - матеріали листування офіційних осіб, надає багато додаткової інформації щодо пошуку відповіді на питання про причини та інституціональні процеси приєднання Криму до складу Росії. Їх особливий антураж у передачі та розкритті ментальних установок і світогляду авторів цих листів і документів, їх персоніфікованого ставлення до тих чи інших подій і фактів. Серед опублікованих матеріалів діловодної документації варто вказати на чотиритомне видання документів «Приєднання Криму до Росії» за редакцією М. Дубровіна. Ці документи характеризують інституціональну історію двосторонніх відносин Росії та Кримського ханства в останній третині XVIII століття. Вони включають у себе: накази Катерини II щодо Кримського ханства, листування з посадовими особами П.О. Рум'янцева-Задунайського, листування 3 посадовими особами Г.О. Потьомкіна, листування представників кримського уряду з російською владою [4].

Опубліковані документи характеризують особливості політичної та соціокультурної ситуації в Криму останньої третини раннього Модерного часу, акцентуючи увагу на взаємовідносинах між Росією, Туреччиною, державами Свропи і Кримським ханством. Важливою віхою в інституціональній історії Криму став Кючук-Кайнарджійський мир 1774 року. За його умовами зберігалася залежність у сфері релігії кримських мусульман від турецького султана - халіфа усіх правовірних. У сфері впливу Туреччини залишалася і фортеця Очаків важливий інституціональний центр в Причорноморському регіоні. Також варто акцентувати увагу на тому, що практично все виробництво і зовнішня торгівля Криму були зоріснтовані виключно на турецький ринок. Цілком логічно, що в економічному відношенні Кримське ханство залишалося залежним від Османської імперії. На той момент Росія ще не мала на Чорному морі жодного свого військового корабля. За своєю сукупністю, усі ці фактори сприяли ослабленню російського впливу в Причорномор'ї. Російський уряд також був зацікавлений у пришвидшенні ратифікації Кючук-Кайнарджійського миру, тому розпочав вивід своїх військ із території Криму [5, с. 84-104].

У цей час до Криму прибуває претендент на ханський престол Дівлет-Гірей. Дівлет-Гірей на початку 1775 року проголосив себе ханом і за допомогою турецьких військ захопив владні повноваження в 
Криму. Щоб заручитися підтримкою Порти, Дівлет-Гірей декларував готовність ліквідувати незалежність Криму. У даному контексті Туреччина порушила Кючук-Кайнарджійський мир через безпосереднє втручання у внутрішні справи Криму. Сахіб-Гірей, який був до цього ханом, у квітні 1775 року залишив півострів. Застосовуючи дипломатичний інструментарій і натякання про розрив відносин із Росією, Туреччина поновила вимагання від неї повернення Кінбурна та Тамані. Влада турецького султана фактично знову поновлювалася над Кримом [6]. Щоб не допустити втрати своїх позицій у Криму, російський уряд прийняв рішення посадити на ханський престол свого ставленика. Ним став калга Шагін-Гірей. Шагін-Гірей висловив прохання до російського уряду надати йому фінансову й військову допомогу, для отримання статусу хана [7].

Скориставшись агресивними діями Туреччини, Росія ввела свої війська. Після введення 23 листопада 1776 року Росією своїх військ до Перекопу, було надано підтримку Шагін-Гірею. За дорученням Катерини II, О.В. Суворов проголосив Шагін-Гірея ханом. Кримський диван відсторонив Дівлет-Гірея і визнав Шагін-Гірея ханом 28 березня 1777 року. 25 серпня 1777 року Катерина II офіційно привітала хана. Саме із цього моменту можливо говорити про інституціональне оформлення протекторату Росії, російського протекторату над Кримським ханством.

Це юридично обгрунтовувалося тією обставиною, що найважливішою ознакою двосторонніх відносин, заснованих на угоді про заступництво, вважається надання державі-протектору зовнішньополітичних прав опікуваної ним держави при формальному збереженні ознак державності [8]. Фактично Шагін-Гірей був зведений на престол силою російської зброї, і це вже не впливало на пошуки юридичного обгрунтування протекторату. Це також слугувало й причиною відмови Туреччиною визнання нового хана. Цілком закономірно, що за таких умов Шагін-Гірей не мав повноважень i можливостей вести самостійну зовнішню політику і за цих обставин змушений був мотиваційно орієнтуватися на Росію. Особиста доля Шагін-Гірея, і Криму в цілому, різко змінилася на початку 1782 року. У цей час -8 квітня 1783 року - було видано Маніфест, згідно із яким проголошувалося включення Кримського ханства до складу Росії. Мотив і пояснення було визначено наступні: порушення Портою угоди про Крим, який став осередком постійної небезпеки для Росії [9].

Росія, у питанні приєднання Криму, провела цілеспрямовану превентивну дипломатичну підготовку серед провідних держав Європи. Зокрема, цьому слугував союз Росії з Австрією, яка 44 
підтримувала Росію в питанні приєднання Криму. Франція та Пруссія, зовні демонстрували незгоду й супротив анексії Криму, але обмежилися в цьому питанні лише дипломатичними нотами. Щодо Османської імперії, то вона під впливом дипломатичного тиску з боку Австрії, Росії та інших європейських держав, визнала факт приєднання Криму до Росії. Унаслідок приєднання, утворилася особлива адміністративно-територіальна одиниця - Таврійська область. До ії складу було включено - півострів Крим, півострів Тамань і степ на північ від Перекопу (між Бердою, Кінськими водами і Дніпром). Інші землі Кубані були територіально приєднані до Кавказької губернії, як такі, що слабко економічно пов'язані з Кримом.

Таким чином, наявний документальний масив джерел констатує, що силовий тиск і втручання в інституціональний розвиток більш слабких держав, із мотивацією захисту інтересів частини ії населення, фактично слугує лише формальним чинником для свого територіального розширення і сфер політичного та інституціонального впливу. Умови для територіально-політичного та політико-дипломатичного приєднання півострова були використані Росією у своїх політичних інтересах у добу раннього Нового часу (в останню третину XVIII століття).

\section{Лiтература:}

1. Інститут рукопису ЦНБ НАН України ім. Вернадського. Спр. 11726. Арк. 40.

2. Російський державний військово-історичний архів (РДВІА). Ф. ВУА. Спр. 186, 211.

3. Російський державний архів давніх актів (РДАДА). Ф.16. Оп.1. Спр. 588, ч. 5,6,7,8,9,10,13; Спр. 693, ч. 6; Спр. 797, ч. 3; - Спр. 800.

4. Дубровин Н. Присоединение Крыма к России: Рескрипты, письма, реляции и донесения: В 4 т. СПб., 1885-1889.

5. Античний Крим: М. Грушевський, Історія України-Руси: В 11 т., 12 кн., редкол.: П.С. Сохань (голова) та ін. К., 1994. Т. І. С. 84-104.

6. Дубровин Н. Присоединение Крыма к России: Рескрипты, письма, реляции и донесения: В 4 т. СПб., 1885-1889.

7. НашКрим $=$ Our Crimea $=$ BizimQirimimiz. Вип. 1: Збірка статей за матеріалами Першої Міжнародної наукової конференції «Крим в історії України», присвяченої 700-літтю спорудження мечеті хана Узбека в Старому Криму / За ред. Д.С. Гордієнка та В.В. Корнієнка. К., 2015. 264 c.

8. Січинський В. Україна і середземноморський простір. Свобода. 1952. № 26-29 (Нью-Йорк, 1952). 
9. Січинський Володимир Юхимович. Крим = Crimea: історичний нарис / Crimea: the historical essay. Нью-Йорк: Орг. Оборони Чотирьох Свобід України, 1954. 31 с.: іл. 